\title{
The Investigation and Trial in Absence, the Procedural Rights of the Defendant and his Lawyer
}

\author{
Adv. Neshet Nguci \\ Chamber of Advocates, Vlora \\ Myzafer Elezi \\ University "Ismail Qemali", Vlora, Department of Justice \\ myzafer.elezi@gmail.com
}

\section{Doi:10.5901/ajis.2014.v3n6p257}

\section{Abstract}

Preliminary investigations constitute the first stage of the criminal proceeding, during which important actions are performed. The bodies of the judicial police and the prosecutor as subjects of criminal law have the right to conduct the restricting of freedom by performing the arrest of defendant when caught in flagrance, or detention of any citizen who is suspected of having committed a criminal offense, if it is proved the existence of this offence. The Start of prosecution is not general but specific, as it is attributed to a particular person, on which there is a reasonable doubt based on evidence that the he is the perpetrator. The criminal proceeding begins with the defendant and the prosecution communication, and other investigative actions, audits, inspections, seizure, confrontation, while the defendant is present, until the conclusion of the investigation. In Albania during totalitarian regime, preliminary investigations were characterized by the inequality of parties, as investigative actions were carried out in secret and the evidences were formed at this stage of the investigation. In 1993 Albania adopted the constitutional provisions on the human rights and fundamental freedoms, and according to them changes were made to the Criminal Procedure Code, which improved the level of criminal proceedings and created the conditions for its further democratization. In the code were clearly defined positions of criminal procedure subjects, by approaching to the ideas of accusatory system of Anglo-Saxon model which guarantees the principle of presumption of innocence, equality of parties, the evaluation of evidence in judicial debate etc.

Keywords: preliminary investigations, the presumption of innocence, trial in absence, judicial punishment.

\section{Procedural Guarantees of the Investigation in Absence}

To ensure the protection of procedural rights and preserving the legitimate rights of a person who is suspected of having committed a crime, the prosecution assigns a defender based on Article 6 of Procedural Criminal Code, lawyers from the available list, when the person under investigation is unable financially to appoint a defender, or his relatives, who plays a unique and important role in preventing violations of law by the proceeding body. But, how effective is the defender appointed by the prosecution in criminal proceedings to realize effective protection in accordance with the procedure, the Constitution and the European Convention on Human Rights? It is worth to discuss.

There are three cases where the defender can be assigned mainly during the investigation:

a) Where a person is arrested on suspicion of committing a criminal ${ }^{1}$ offense and will not or can not take a lawyer.

b) When detained on suspicion of having committed a crime in a previous time ${ }^{2}$, when he or his relatives are unable to support financially the appointment of a lawyer.

c) When the person suspected of committing a crime is absent and not a particular representative is left to defend his procedural rights in criminal proceedings against him.

In case of arrest or detention, the person under investigation is informed of the appointment of the lawyer and he gets in touch with him and is present in all procedural actions until the completion of the preliminary investigation. The

${ }^{1}$ Article 251 of the Criminal Procedure Code of the Republic of Albania.

${ }^{2}$ Article 253 of the Criminal Procedure Code of the Republic of Albania. 
lawyer assigned mainly and the defendant acquire knowledge on acts, like the question of the person under investigation under section 256 of Criminal Procedure Code, the decision to extend the time limit for investigation, under section 324 of Criminal Procedure Code, the notice of prosecution decision to take as defendant the person under investigation under section 34 of $\mathrm{C}$. Pr. Code, the minutes of recognition acts after the investigation and request for trial. When a person suspected of a crime is in default, the security measures taken in the absence of the suspect and the defense lawyer, the prosecutor's request ${ }^{3}$, bring together data and acts that indicate the existence of conditions and criteria for determining a measure of security. ${ }^{4}$

The procedure for appointing the lawyer mainly provides that "where a person against whom the measure is taken is not found, the judicial police officer keeps the minutes of the research made and sends it to the court which delivered the judgment"5. The paragraph 2 of this Article stipulates that: "When the court finds that full searches are done for the person declares its absence," and paragraph 3 of this Article states that: "With the act that declares the absence, the court appoints a lawyer to the person who has fled and orders to be deposited in the secretary a copy of the decision in which is appointed the implemented measure". While the procedure for the issuance of the order of not finding the person and appointment of the lawyer mainly for the notice of charges provided under this provision made by the prosecutor, namely: "If the search does not give a positive result, then is extracted a not finding order, which is noticed to the lawyer of the defendant who is considered his representative, by delivering a copy of it," 6 . This decision extends the effects until the completion of the investigation or judgment from the court. In parallel to the first paragraph and Article 141/3 of Criminal Procedure Code, which states: "Notice to the Defendant hidden or runaway, done through a copy of the act delivered to the defender and when there is no lawyer, the proceeding authority appoints a lawyer mainly who represents the defendant". So this provision is clear that the actions of not finding and decision competence and appointing lawyer during the preliminary investigation mainly, are under the prosecutor, Article 247 Criminal Procedure Code, which is made a practice of the proceeding body.

\section{The Efficiency of the Defender Appointed Manly}

In case of arrest in flagrance or detention, the role of lawyer assigned by the prosecution is mandatory, from the beginning until the end of the investigation ${ }^{7}$, and is somewhat efficient, because the defendant has the opportunity to contact lawyer and talk with him. If the defendant is absent, the question is different, because of the role of the lawyer appointed mainly is almost non - existent and as we know from the practice talking about a protector who does not know his client feels no responsibility which defines article 12 of law on the Advocacy, to realize an efficient protection in fulfillment of his duty. From investigative and judicial practice is proved that lawyer appointed mainly, elected by the prosecution are not selected from the list in the order of the Advocacy room, but not taxable lawyer, who possess the advocacy license, and the goodwill of proceeding body without respecting the rules and law of advocacy. Indeed, these so-called lawyers, are few in number, but very damaging to the interests of "their" clients for whom they do not care, and they sign procedural acts dealing with the question of the defendant notice of the charge, the request for trial without being present. This means that the defender cannot make an efficient protection, and is a manipulator of the criminal process in cooperation with the prosecution and in most of the cases if not in all cases, the appearance of the defendant and restoring term under section 147/2 of Criminal Procedure Code, decisions emerging from this process are vulnerable.

So, although it is provided by Article 49/3 of Criminal Procedure Code, criteria for appointing a lawyer mainly, as mentioned above, always the defender generally cannot realize that the law recognizes rights to the defender specifically authorized by the defendant, the rights provided in Article 410/2 of Criminal Procedure Code. In this context, the Supreme Court stated in the unifying decision, no. 354/1999:

"In case of a absent judgment under the second paragraph of this article 410/2, where the defendant does not exercise the right of appeal, this right the law to the defender specifically authorized by the defendant to exercise it", and following up, this court stated: "Protecting mainly presume proceedings and ensuring a fair trial, respect for the rights and freedoms

\footnotetext{
3 Under Section 244 of C. Pr. Criminal - Request for appointment of security measures.

${ }^{4}$ According to Chapter I - personal security measures.

${ }^{5}$ According to Article $247 / 1$ of C. Pr. criminal

${ }^{6}$ Article 141 of C. Pr. criminal

${ }^{7}$ Article 49 of C. Pr. criminal
} 
of defendants in criminal proceedings, but never the overall availability of the rights known by law". ${ }^{8}$

So, the reasoning of the United Colleges is clear that the rights of defense, in the absence of the defendant expire at the conclusion of the trial at first instance, which means that the defender no longer exist as a party in the trial and therefore, no longer enjoys rights law recognizes to the parties in the criminal process.

In my opinion, referring to the legislation in force, assigned lawyer mainly in the absence of the defendant is a statistical procedure for investigation and trial, but, referring to the case law in the end is not efficient, because after the end of the scales of the judiciary, starts a new process with the presence of the defendant, which brings new arguments, and therefore a decision different from the first. This means, an investment of the prosecution and the court, a wasted time, a cost to the state. Seeing that the role of the defender appointed mainly, in the absence of the defendant is formally unable to realize effective protection in accordance with the Constitution of Albania "Everyone has the right to be heard before being judged" 9 as well as the European Convention on Human Rights man, "the right to a fair trial"10, it would be good to process and all parties, and providing that the legislator suspend the investigation and trial in absence, extending the period of limitation of criminal prosecution.

\section{Cases of Investigation in the Absence}

Under Albanian law ${ }^{11}$, enriched with judicial practices, is known investigation in the absence of the defendant and only in two cases is suspended the investigation:

- When the author is not known.

- When the defendant suffers from a serious illness that prevents further investigation.

A person may be prosecuted in his absence when after the start of the criminal case, according to Article 24 of Criminal procedure Code, proceedings body is entitled to carry out investigative actions. With the launch of investigations, has the obligation, that the person under investigation has not selected a lawyer for various reasons in support of Article 49 of Criminal procedure Code, proceeding authority appoints a defense lawyer mainly.

\section{The Defendant's Trial in Absence}

The trial of the accused in absence, accepted by criminal procedural law in our country, is a choice between the public interest, to punish crime committed by individuals, on the other hand, it is the right of the defendant to be present and to be heard and judged. By the legislator this conflict of interest is resolved in favor of the public ${ }^{12}$ interest, by accepting an absence judgment institute initially with the Code of Criminal Procedure in 1995 and in 1998 was sanctioned by the Constitution, but on the other hand, efforts were made to ensure minimum standards, individual rights, in the criminal proceedings, without denying the defendant a fair hearing. So, is intended to protect the interests of the state and individuals harmed by the offense, but, without denying the procedural rights of a person charged with a criminal offense.

Forecast to proceed in the absence code is done with good intention to strike quickly and immediately offenses and increase the effectiveness of the fight against crime ${ }^{13}$. If the trial will not be allowed in the absence would cause paralysis of judicial processes to some extent, given the consequences that may result from the disappearance of evidence of periods of investigation or an imbalance and fading of justice..$^{14}$

\footnotetext{
${ }^{8}$ No. unifying decision. 354/1999, High Court.

${ }^{9}$ Article $33 / 1$ of the Constitution of Albania

${ }^{10}$ Article 6 of the European Convention of Human Rights

11 See: Law no. 7905 dated 21.3.1995.

${ }^{12}$ Albania is a country still in transition, with major problems in the population and the fact of migratory movements and migration, factors that constitute the objective difficulties prosecuting authorities in finding the defendants regardless of searches made. It appears that the trial in the absence of the defendant fits the current climate in Albania, because the opposite would lead to endless delays and criminal proceedings in a trial stagnation.

13 Ylvi Myrtja, "Gjykimi në mungesë", Trajtime Juridike, 2001.

14 "Për një rend publik Europian", Vëllimi I, 2001, fq. 648. This argument was used by the Italian government to justify the application of a default judgment in the case Coloza $v$ Italy. "According to the government the right to participate personally in the trial is not absolute in character, (a concept that at first glance given by the Commission in its report) it must be matched by a" reasonable equilibrium "with the public interest and the interests of important justice".
} 
Article 6 of the European Convention on Human Rights provides for the right of every person to a fair hearing, which means that a process should provide minimum guarantees provided by the convention. Although not explicitly mentioned in paragraph 1 of Article 6, the object and purpose of this article taken as a whole, show that a person charged with a criminal offense has the "right" to participate in the trial. Subparagraphs c), d) and e) of paragraph 3 shall guarantee to every person accused of a crime the right to be defended in person, or ask to examine witnesses and to have the free assistance of an interpreter if he cannot understand or speak the language used in court, and it is difficult to understand how he can exercise these rights without being present in the process. ${ }^{15}$

But the Strasbourg Court in the case Sejdovic against Italy stated:

"The trial in absence is not contrary to the spirit of Article 6 of the ECHR, provided that the defendant be informed effectively to process that is launched against him or he has given up in order to express the right him to be present at trial and to ensure unlimited possibility for a new process in his presence".16

As shown, the European Court of Human Rights does not necessarily require states to ensure the defendant's presence at trial, the opposite would lead to the elimination of the Institute of absent judgment, but requires that the tools provided by the domestic law of the defendant and the judge convicted in absence, has neither waived his right to be present during the trial, nor has not been absconded, should be effective. ${ }^{17}$

Trial in absence is regulated in the Constitution and the Criminal Procedure Code in our country. Article 33 of the Constitution provides that "Everyone has the right to be heard before being judged. Does not benefit from this right the person who is hidden to the justice". In this regard concluded that the defendant's right to be present at trial is not absolute, but contains in itself the possibility of limiting this right. Restrictions on the right to be present at trial must be in accordance with Article 17 of the Constitution ${ }^{18}$, therefore should not affect the essence of the right.

Referring to Article 33 of the Constitution we conclude that the presence of the defendant at trial constitutes a right to, but not an obligation as in Germany, therefore only when it is proved that the defendant evade justice or unwilling to use the right him to be present at trial, he could be tried in absence. By absconded or not the defendant loses the right to be heard, but not the right to a fair trial. In Article 353 Criminal Procedure Code, Provides the only criminal case where the defendant can be involuntarily accompanied to court, when it is not present or is declared in absencde, if his presence is necessary for obtaining a test, but not for his question.

\section{Cases of Judgment in Absence}

Under and pursuant to Section 352 of the Criminal Procedure Code, the court may adjudicate in absence if:

- He seeks or consents to judicial review be done in his absence, or being imprisoned, refuses to participate represented by the lawyer.

- When the defendant, who is presented, leave the room itself is considered present ${ }^{19}$, provided that represented by lawyer.

- The trial in absence can be done, when is proved that the defendant is evading the trial.

Criminal Chamber of the Supreme Court Decision no. 602, dated 26.09.2007:

"It appears that the defendant O.M., judged by precautionary measures "detention"for the hearing on 21.12.2005 have notified the court of appeals that cannot attend the trial for due to bad health condition, and have demanded that the ruling did not proceed without their presence. By the Court of Appeal Gjirokastra, although not given consent of the defendants were arrested, and no further verification to prove the opposite of their claim, the trial of the case is decided in the absence of the defendants. With this decision has not been agreed by lawyer assigned to defendant, who also refused to defend their interests without prior consent for this kind of representation. Contrary to the requirements of Section 352 of

\footnotetext{
${ }^{15}$ Për një rend publik Europian", Vëllimi l, 2001y fq. 647

${ }^{16}$ Strasbourg Court in the case Sejdovic against Italy.

17 The European Court of Human Rights, RR v. Italy, judgment no. 42191/02, dated 09.06.2005, § 51.

${ }^{18}$ Article 17 of the Constitution "1 - limits the rights and freedoms provided for in this Constitution may be imposed by law in the public interest or for the protection of the interests of others. Restrictions must be proportionate to the situation that has dictated it. 2 - These limitations may not violate the essence of freedoms and rights, and in any case can not exceed the limits laid down in the European Convention of Human Rights".

${ }^{19}$ Criminal Chamber of the Supreme Court Decision no. 602, dated 26.09.2007.
} 
C. Pr. Code Appeals Court Gjirokastra continued trial of the case in the absence of the defendants SO and VM, and decided to realize their defense lawyer assigned by the court of appeals".

Thus, the court in essence, no one has the right to judge the defendant in absence if he has not given his consent (to have waived clearly and deliberately out of his right to be present during trial). Precisely for this reason the defendant should be notified to effectively proceedings initiated against him, that he wants to decide for themselves whether or not to be present during the trial.

Criminal Chamber of the Supreme Court Decision no. 38, dated 08.04.2004 states:

"The participation of the defendants or detainees free, even in the hearing of the appeal in the Court of Appeal against the decision of the court of first instance regarding the prosecutor's request for validation of his detention and for determining a measure of personal security trial detention, when the defendant himself has expressed a desire to participate, regardless of attorney previously issued to represent him in his absence by the defense, is a legal obligation for the court and disregard of this obligation constitutes a violation the constitutional right to a fair hearing". ${ }^{20}$

There is the price of court if the defendant should or should not attend the trial, it has the obligation to inform the defendant of the date and time of the trial, and is a defendant's choice whether to participate or not in trial. In the case where the defendant is incarcerated, the court informs the defendant and state authorities holding the prisoner have the obligation to create all the opportunities that he be present during the trial and inform them of this right. This is due to the fact that the defendant is imprisoned is in a disadvantageous position that the defendant free, therefore, to state obligations arise as a result of restriction of liberty that has been made defendants. ${ }^{21}$

The absence of the defendant can be classified 22 as:

a) Lack of voluntary ${ }^{23}$ when the defendant evades justice, or does not wish to participate in the trial.

b) No involuntary when the defendant fails to appear at trial because it was aware that it was being held to a trial or could not appear in court because he has been an absolute impossibility.

Criminal Procedure Code provides for some cases when the defendant with his free will does not have the right to be present at trial:

a) When a defendant seeks or consents to trial in absentia, having been imprisoned or refuses to participate (Article 352/1 of the Code of Penal Procedure).

b) When the defendant appeared before the court though, voluntarily leave the room (Article 352/2 of the Code of Penal Procedure).

c) If it is proved that the defendant evades justice (Article 352/4 of the Code of Penal Procedure).

d) Where the defendant free or detained although not appear at the hearing and was informed there were no legitimate reasons for not appearing (Article 351/1 of the Penal Procedure Code ${ }^{24}$ ).

Unless the absence is voluntary may have cases where the absence may be due to causes independent of the will of the defendant which are:

a) If the defendant had no knowledge of the proceedings (Article 351/2 and 427/4 of C. Pr. Penal).

b) When the defendant even though there were not aware of the proceedings could be filed for a legal reason has been unable or absolute (Article 351/2 and 427/4 of C. Pr. Penal repetition of judicial review in the Court of Appeal).

c) When the order of the president of the defendant issued by hearing room, for his improper behavior which has become an obstacle to the development of the hearing (Article 344/2 of C. Pr. Penal).]

20 Criminal Chamber of the Supreme Court Decision no. 38, dated 08.04.2004

${ }^{21}$ Stephanos STAVROS, "The guarantees for accused person under article 6 of The European Convention on Human Rights", fq.197.

22 Ylvi Myrtja, "Gjykimi në mungesë", Trajtime Juridike, 2001

${ }^{23}$ Black's Law Dictionary, sixth edition, WEST publishing 1990, pp. 330, The defendant in absentia defines as "One accused of a crime to refuse to appear and answer the allegations made", appears to involve only voluntary absence".

${ }^{24}$ Article $351 / 1$ of $\mathrm{K}$. Pr. Criminal is a material error in its formulation, he says "... and there were legitimate reasons to appear ...", but can not be assumed that the court declares the absence of the defendant because he: "did not had legitimate reasons to appear "but because" there were no legitimate reasons for not appearing". So part missing "not". 


\section{Procedural Guarantees of Trial in Absence}

To respect the rights guaranteed by Article 6 of the European Convention of Human Rights when the defendant is in absence, and the situation becomes problematic, rather than he is on trial. The whole institute in absence judgment revolves around the problem when it can be said that the defendant was informed of the charges effectively and when it can be said that he has waived his right to attend the trial without doubt that we are wrong! Trial procedure when we are in the defendant's absence is almost similar to ordinary judgment, but, given some specific characteristic. Not forgetting the fact that the defendant is not present, is in an unfavorable position than one who is present. In the Code of Criminal Procedure provides for a series of guarantees in order that the defendant be granted in the absence of due process of law.

Often the cause for annulment of the decision of a court made disregard legal requirements for disclosure and lack of guarantees that the following. ${ }^{25}$

\section{Voluntary Waiver to be Present at Trial}

The defendant may be tried in absencea unless waived expressly and voluntarily from his right to be present at trial. Article 352 of C.Pr. Code provides criminal trial in absencea when he asks himself or refuses to appear, when leaving the room or when he fled law enforcement officials who accompany detainees as and when it is presented during the investigation and trial. Request or consent of the defendant that the trial proceed in his absence, should be made at the hearing or submitted in writing to the court ${ }^{26}$, through counsel or mail, but confirmed his signing with the manner provided by law (with notarial act). In the case where the defendant refuses to appear, or leave the room when he fled law enforcement officials, resulting from the action waiver. Hiding the defendants to avoid trial must be proved by the prosecution, which is obliged to submit documents and evidence to prove that the defendant does not wish to participate in the trial and therefore, eg The defendant escapes an attempt to arrest by police authorities.

However, the Code of Criminal Procedure provides the trial in absence of a defendant who fails to appear in court without legal grounds (Article 351/1 of C. Pr. Penal), although respecting all the legal procedures of notification and communication acts. In this case, the waiver of the right to be present at trial and the defendant will be presumed from the fact that although taken all necessary actions to notify the defendant, he is aware of the announcement that is made knowingly and again fails to appear at trial and while not represent nor reasons to justify his absence.

In our law, the defendant is known all rights to participate in the trial and the right of his knowledge of the allegations and said there is no provision in the lack of such procedural rights mentioned above, but allowed that through the implementation of several mechanical procedures are often dealing with notifications, be presumed that the defendant has been informed effectively, actions which lead to the presumption that the absence is voluntary. ${ }^{27}$

For the European Court of Human Rights are not enough presumptions and "judicial functions" to be sure of an effective notice or an expressed waiver. In other countries the presence of the defendant is necessary to be familiar with the charges that were brought against him, and dealing with them, is a right that almost cannot be waived and, in the few cases that are allowed, should that the waiver be expressed and made directly by the person before proceeding body in shape to provide the defendant derived from waiver and not based on assumptions. The defendant, who has changed residence and has not made the appropriate changes, cannot be made aware of that proceeding was initiated against him. For other European countries and the European Court of Human Rights, the effective recognition of the charges and taking part in the trial cannot be crossed with a judicial function, and in the case of a conviction in absence should be guaranteed at least the possibility to have a "fresh determination of the merits of the charge" 28 so a new process in which the convicted in absentia have the right to raise claims of fact or law in relation to charges attributable.

\footnotetext{
${ }^{25}$ Criminal Chamber of the Supreme Court, Decision no. 410, dated 18.04.2007.

${ }^{26}$ Halim Islami, Artan Hoxha, Ilir Panda "Komentar i Procedurës Penale", botime "Morava", 2003, fq. 475.

${ }_{27}$ (Fredi Paskali, "Gjykimi në mungesë i të pandehurit", Tribuna Juridike, nr. 30 2001, fq. 20). A part of lawyers continue to disagree with the judgment in absentia, with the argument that as long as he is not communicating counts can not get the quality of the defendant.

28 Principle mentioned in several decisions of the European Court of Human Rights, such as Italy v Coloza decision dated. 02.12 .1985 and the Decision no. 277, dated 11.23.1993, Poitrimol v France, "When domestic law allows for a trial despite the absence of the person charged with the crime, which may be in the position of Mr Coloza, this person at the moment that is aware of the process, should be able to take, the court has heard that a fresh decision on the merits".
} 


\section{Conclusions}

At the conclusion of this paper we present some conclusions and some general recommendations regarding the issues found.

1. Trial in absence is an exception to the rule, since the process should normally take place in the presence of the defendant. In some countries of the continent trial in absence is provided only in some cases, and the defendant may be sanctioned to discourage this absence. In Albania, a defendant who is absent not only is not penalized, but his judgment guarantees a number of other added guarantees, because the person who is in absence is in a position less favorable since it is not present to perform its protection. The defendant may be tried in absence waived only when clearly and deliberately out of his right to be present during the trial. The presence of the defendant at trial constitutes a right and not an obligation. Over the proceeding burdens obligation to create conditions that defendant he realize his right to be present during the trial. Waiver to be present during the trial can be done with a declaration before the court or be sent in writing it. Voluntary absence of the defendant may also result from final actions such as when it is proved that the defendant evaded the trial (it must be proved by the prosecutor), when abscond or leave the courtroom etc. However the defendant has the right to appear at any time during the trial.

2. If the court finds the defendant's absence it is required to verify the causes of absence. If it is confirmed that the absence has been no fault of the defendant but for other reasons independent of his will, then the court must defer or suspend judgment and to reiterate the announcement. The same rules apply to defense. When the trial is conducted in absence and later emerges that his absence was involuntary because he did not receive notice or that it has been unable to display absolute decision declaring lack is invalid. Will be deemed to be unable to display the absolute defendant to be tried or is serving a sentence in another country. If he wants to be present at the trial court is obliged to suspend consideration of the case until it enables the transfer or extradition.

3. In Albania, if implemented all procedures provided for notification of the defendant, even mechanically, it is presumed that the defendant was aware of the proceedings initiated against him. From a presumption arises a presumption, if a defendant who is presumed notified effectively presumed not presented at trial that his absence is voluntary. Thus arises the perfection of the system of notifications in order not to create room for assumptions that lead right to trial without a defendant in his absence by denying the right to be present during the examination of the case in charge of thereof.

4. The decision was made in the absence of the defendant must be notified to him under the rules for notifications. He has the right to appeal and if the appeal it is proved that the defendant did not take part in the trial that was conducted in the first instance because it had no knowledge or because there were legal reasons, the court is obliged to repeat the trial.

5. The right of appeal is a constitutional right, guaranteed by international acts as an indispensable tool in a state of law recognizing the defendant the possibility of a second opinion on the matter in his charge. In the case of a judgment given in the absence of the defendant's right to appeal this decision unless the defendant recognized his lawyer chosen by the family or designated by the court, although there is a special proxy of latter.

Recognizing the right of the defense to appeal, quenching the defendant's right to apply to be reinstated within his right to appeal. For once exhausted complaint cannot be resubmitted. In this way the defendant is unjustly denied the possibility that the issue be examined in his presence. Is not realized what ECHR calls "fresh Determination of the merits of the charge" so a new process in which the convicted in absence have the right to raise claims of fact or law in relation to charges attributable.

I think intervention is necessary to fix this legislator legal defect. It should provide a remedy capable allow the defendant, who through no fault of his tried and convicted in absence, a new trial fact after he appears.

\section{References}

Constitution of the Republic of Albania, promulgated by decree of the President of the Republic no. 2260, date. 28/11/1998.

Halim Islami, Artan Hoxha, Ilir Panda "Komentar i Procedurës Penale", botime "MORAVA", 2003

Fredi Paskali, "Gjykimi në mungesë i të pandehurit", Tribuna Juridike, nr. 302001.

Ylvi Myrtja, "Gjykimi në mungesë", Trajtime Juridike, 2001

Stephanos STAVROS, "The guarantees for accused person under article 6 of The European Convention on Human Rights". 
Black's Law Dictionary, sixth edition, WEST publishing 1990.

Deklarata Universale e të Drejtave të Njeriut, ratifikuar me ligjin, nr. 7692 datë 31.03.1993.

Pakti Ndërkombëtar për të Drejtat Civile dhe Politike, ratifikuar me ligjin nr. 7510, datë 08.08.1991.

Konventa Evropiane e të Drejtave të Njeriut, ratifikuar me ligjin nr. 8137, datë 31.07.1996.

Kodi i Procedurës Penale i Republikës së Shqipërisë, miratuar me ligjin nr. 7905, datë 21.03.1995, botim i Qendrës së Publikimeve Zyrtare.

Ligji "Për disa ndryshime në Kodin e Procedurës Penale" nr. 8813, datë 13.06.2002.

Vendimi unifikues nr. 354 /1999, i Gjykatës së Lartë.

Konventa Europiane të të Drejtave të Njeriut

Gjykata e Strasburgut në çështjen Sejdovic kundër Italisë.

Gjykata Europiane e të Drejtave të Njeriut, R.R. v Italisë, vendim nr. 42191/02, datë 09.06.2005, § 51 .

Kolegji Penal i Gjykatës së Lartë, Vendim nr. 602, datë 26.09.2007

Kolegji Penal i Gjykatës së Lartë,Vendim nr. 38, datë 08.04.2004

Kolegji Penal i Gjykatës së Lartë, Vendim nr. 410, datë 18.04.2007.

Gjykata Europiane të të Drejtave të Njeriut, Vendimi Coloza v Italisë i dt. 12.02.1985 dhe vendim nr. 277, datë 23.11.1993, Poitrimol v Francës. 